\title{
Peningkatan Hasil Belajar IPA Materi Siklus Air Menggunakan Model Problem Based Learning dengan Media Diorama
}

\author{
Rizky Yuniarsih \\ Universitas Sebelas Maret \\ rizkyyuniarsih.9c@gmail.com
}

\section{Article History}

received 30/4/2021

revised 30/5/2021

accepted 30/6/2021

\begin{abstract}
Classroom Action Research (CAR) is motivated bythe results of learning science of water cycle material, students of class V SDN Kluwut 04 still have not reached the minimum completeness criteria (KKM). This study aims to improve learning outcomes in Natural Sciences on water cycle materials using a problem based learningmodel with diorama for fifth grade students at SDN Kluwut 04, for the 2020/2021 academic year. The researcher carried out the CAR in two cycle and each cucle was meeting. The results of the research on pre-cycle actions thet had $12 \%$ classical completeness with an average value of 55 experienced an increase in the first cycle of actions. In the first cycle classical completeness reached $74 \%$ and an average value of 77. The study ended in the second cycle achieving $100 \%$ classical completeness and average value is 97. Based on the results of the study, it can be concluded thet the applicationof the problrmbased learning model can improve the science learning outcomes of water cycle material for the fifth grade studentsof SDN Kluwut 04 Brebes for the 2020/2021 academic year.

Keywords: Learning Outcomes, Diorama Media, Problem Based Learning
\end{abstract}

\begin{abstract}
Abstrak
Penelitian Tindakan Kelas (PTK) dilatar belakangi hasil belajar IPA materi siklus air peserta didik kelas V SDN Kluwut 04 masih belum mencapai kriteria ketuntasan minimal (KKM). Penelitian ini bertujuan untuk meningkatkan hasil belajar IImu Pengetahuan Alam materi siklus air menggunakan model problem based learning dengan media diorama pada peserta didik kelas V SDN Kluwut 04 Kabupaten Brebes tahun ajaran 2020/2021. Peneliti melaksanakan PTK dalam dua siklus dan masing-masing siklus dilaksanakan dalam satu pertemuan. Hasil penelitian pada tindakan prasiklus yang memiliki ketuntasan klasikan $12 \%$ dengan nilai rata-rata 55 mengalami peningkatan pada tindakan siklus I. Pada siklus I ketuntasan klasikal mencapai $74 \%$ dan nilai rata-rata 77 . Penelitian berakhir pada siklus II mencapai ketuntasan klasikan $100 \%$ dan nilai rata-rata 97 . Berdasarkan hasil penelitian tersebut dapat disimpulkan bahwa penerapan model pembelajaran problem based learning dapat meningkatkan hasil belajar IPA materi siklus air pada peserta didik kelas V SDN Kluwut 04 Brebes tahun ajaran 2020/2021.
\end{abstract}

Kata kunci: Hasil Belajar, Media Diorama, Problrm Based Learning 


\section{PENDAHULUAN}

Kemajuan suatu zaman akan menuntut negara untuk mengikuti perkembangan melalui sumber daya manusianya. Pengembangan potensi sumber daya yang ada diharapkan negara dapat berkualitas. Salah satu cara yang dapat dilakukan agar sumber daya manusia berkualitas adalah tersedianya pendidikan yang baik. Jadi suatu negara perlu memfasilitasi seluruh warganya untuk memperoleh pendidikan sesuai dengan UUD 1945 Pasal 31 Ayat 1 yang berbunyi "Setiap warga negara berhak mendapat pendidikan". Berdasarkan apa yang tertulis dalam UU Nomor 20 Tahun 2003 mengenai Sistem Pendidikan Nasional Bab I Pasal 1 Ayat 1 bahwa pendidikan adalah cara yang dapat dilakukan untuk mengembangkan kemampuan manusia seoptimal mungkin melalui pengembangan potensi sehingga menjadi pribadi yang berkualitas. Yusuf (2014:78) menyatakan bahwa pendidikan berguna meningkatkan karakter sumber daya manusia. Jika dalam pelaksanaan pendidikan didukung dengan sumber daya berkualitas maka proses pendidikan menjadi berkualitas. Pengembangan potensi tersebut dapat dilakukan sedini mungkin, salah satunya dilakukan pada jenjang sekolah dasar. Susanto (2013:70) mengemukakan bahwa pendidikan di sekolah dasar berfungsi sebagai upaya pengembangan potensi diri melalui pembelajaran aktif sehingga peserta didik dapat termotivasi dan mengoptimalkan diri dalam suasana yang kondusif. Pembelajaran di sekolah dasar dilaksanakan secara terpadu atau dikenal dengan pembelajaran tematik.

Sa'ud (2013) mengemukakan pembelajaran tematik merupakan pembelajaran yang menggabungkan beberapa muatan pelajaran menjadi satu dalam sebuah tema. Adapun muatan pelajaran yang dikembangkan adalah muatan Pendidilan Pancasila dan Kewarganegaraan (PPKn), Bahasa Indonesia, IImu Pengetahuan Alam (IPA), IImu Pengetahuan Sosial (IPS), Seni Budaya, dan Prakarya, serta Jasmani, Olahraga dan Kesehatan. Rusman (2015:358) mengemukakan pembelajaran tematik terpadu merupakan salah satu pendekatan dalam pembelajaran terpadu (integrated instruction) yang merupakan suatu sistem pembelajaran yang memungkinkan peserta didik baik secara individual maupun kelompok, aktif menggali dan menentukan konsep serta prinsip- prinsip keilmuan secara holistik, bermakna, dan autentik.

Berdasarkan pengertian di atas dapat disimpulkan bahwa pembelajaran tematik terpadu merupakan model pembelajaran terpadu yang melibatkan beberapa mata pelajaran untuk memberikan pengalaman bermakna kepada peserta didik. Pada kenyataannya pembelajaran tematik yang dilakukan di sekolah dasar belum mampu terlaksana dengan maksimal. Pengamatan pembelajaran dilakukan pada peserta didik kelas V SD Negeri Kluwut 4 Kecamatan Bulakamba Kabupaten Brebes yang dilakukan secara tatap muka adalah pembelajaran yang berpusat pada peserta didik (student centered), guru melibatkan peserta didik dan aktif dalam pembelajaran, namun pada kenyataan kemampuan peserta didik dalam proses terutama dalam mengamati, menanya, mencoba, mengolah, menalar, mencipta, menyajikan, dan mengkomunikasikan masih rendah. Berdasarkan kegiatan prasiklus untuk materi siklus air pada tema 8 (Lingkungan Sahabat Kita), didapatkan data bahwa dari 27 peserta didik hanya 4 peserta didik atau $12 \%$ dari jumlah seluruh peserta didik yang mendapat nilai $\geq 75$. Sedangkan 23 peserta didik atau $88 \%$ peserta didik masih belum mencapai KKM. Berdasarkan hasil kegiatan tersebut diperlukan model pembelajaran dan media pembelajaran untuk meningkatkan hasil belajar IPA. Salah satu model pembelajaran yang menarik adalah model pembelajaran Problem Based Learning (PBL) dan media pembelajaran Diorama.

Barrow (1980) dalam Huda (2017:271) mendefinisikan bahwa di dalam model pembelajaran $\mathrm{PBL}$ pertemuan pertama diberikan suatu permasalahan sehingga peserta didik mendapatkan pemahaman akan resolusi. Lebih lanjut, (Rusmono 2017:74) menyatakan bahwa dalam strategi pembelajaran PBL hal yang dilatih adalah kebebasan peserta didik dalam pembelajaran. Ciri dari model Problem Based Learning 
(PBL) adalah dengan menggunakan masalah di kehidupan nyata. Jadi dalam pembelajaran ini peserta didik menjadi pusat pembelajaran dan bukan guru. Pembelajaran IPA materi siklus air menggunakan model pembelajaran PBL perlu menggunakan media untuk membantu peserta didik agar dapat menerima pembelajaran secara optimal. Muhsetyo dkk. (2014:23) menyatakan bahwa suatu alat yang digunakan guru dalam mempermudah proses pemberian materi pelajaran sehingga peserta didik dapat terlibat langsung dalam pembelajaran yaitu media. Media adalah salah satu kunci keberhasilan dalam kegiatan pembelajaran. Guru perlu dibantu oleh media dalam pembelajaran agar peserta didik dapat melaksanakan pembelajaran secara optimal. Salah satu media yang menarik adalah media diorama. Sudjana dan Rivai (2011:170) mengemukakan media diorama adalah pemandangan sebuah dimensi mini, bertujuan untuk menggambarkan pemandangan sebenarnya. Penelitian ini menggunakan media Diorama.

Penelitian mengenai model PBL untuk meningkatkan hasil belajar IPA SD pernah dilakukan oleh Septian Apendi mahasiswa Universitas Pendidikan Indonesia melakukan penelitian dengan judul skripsi "Penerapan Metode Problem Based Learning dengan media Diorama untuk Meningkatkan Hasil Belajar IImu pengetahuan Alam pada Konsep Makluk Hidup dan Lingkungannya" (Penelitian Tindakan Kelas) di SDN 1 Lebak siuh Kelas IV Semester II Tahun Ajaran 2011/2012 Kecamatan Kadudampit Kabupaten Sukabumi). Masalah yang dihadapi peneliti adalah masalah guru di SD yang dalam mengajar lebih banyak mengejar target nilai ujian akhir yang melebihi KKM, namun tidak melihat pada masalah yang dihadapi oleh peserta didik, aktivitas guru lebih dominan daripada peserta didik, akibatnya guru seringkali mengabaikan proses pengalaman belajar akan menambah nilai hasil belajar peserta didik. Septian Apendi menarik kesimpulan, bahwa dengan penerapan Problem Based Learning dengan media Diorama dapat meningkatkan hasil belajar dan pemahaman peserta didik dalam pembelajaran IPA, metode ini juga sangat melatih keterampilan peserta didik dalam memecahkan masalah. Pembelajaran penggunaan PBL dapat memfasilitasi keterlibatan peserta didik baik yang berprestasi tinggi, sedang, ataupun rendah, karena peserta didik selalu diikut sertakan dalam seluruh kegiatan pembelajaran. Pada siklus III peserta didik sudah mampu memahami materi makhluk hidup di lingkungannya. Sikluspun dihentikan dan dinyatakan berhasil. Beberapa kajian empiris tersebut menjadi landasan peneliti untuk mengadakan penelitian menggunakan model pembelajaran PBL dengan media Diorama dalam pembelajaran IPA pada peserta didik kelas V materi siklus air pada tema 8 (Lingkungan Sahabat Kita).

\section{METODE}

Penelitian ini merupakan penelitian tindakan kelas untuk meningkatkan hasil belajar IPA materi siklus air menggunakan model pembelajaran problem based learning dengan media Diorama. Penelitian ini akan dilaksanakan dalam 3 siklus dengan tahapan setiap siklusnya adalah perencanaan, pelaksanaan tindakan, pengamatan dan refleksi Kunandar (2012:71-76). Prosedur penelitian ini mengacu pada model Kemmis dan M.C Taggart yang terdiri atas empat komponen. Berdasarkan hasil analisis siklus I, II dan III terhadap pemahaman konsep IPA materi siklus air. Maka peneliti menyimpulkan apakah hipotesis tindakan tercapai atau tidak jika penggunaan model pembelajaran problem based learning dengan media Diorama dapat meningkatkan hasil belajar IPA materi siklus air peserta didik kelas V SDN Kluwut 4.

Analisis data yang digunakan dengan analisis data kuantitatif untuk menganalis data berdasarkan hasil belajar siswa selama mengikuti pembelajaran. Analisis data penelitian untuk diberikan tindak lanjut berupa observasi kepada siswa serta dengan analisis deskriptif untuk memaparkan data yang dihasilkan dari penelitian yang dideskripsikan sesuai dengan data yang telah terkumpul. Suyadi (2010:23) 
menyebutkan bahwa teknik pengumpulan data merupakan langkah yang paling utama dalam penelitian, karena tujuan utama dari penelitian adalah memperoleh data. Data yang sudah terkumpul akan diuji untuk diverifikasi menggunakan diskusi teman sejawat maupun antar anggota. Teknik analisis data yang digunakan dalam penelitian ini meliputi: Penyimpulan data hasil observasi guru dan siswa dilakukan dengan melihat lembar hasil observasi yang telah diisi oleh observer selama pembelajaran berlangsung dan komentar perbaikan dari observer, dokumentasi berupa foto-foto dan video pembelajaran per siklus yang menjelaskan kegiatan pembelajaran di kelas $\mathrm{V}$ SDN Kluwut 4, tes berupa tes tertulis dan bersifat pilihan ganda yang mengacu pada indikator pemahaman konsep.

\section{HASIL DAN PEMBAHASAN}

Penelitian ini merupakan penelitian tindakan kelas (PTK). Penelitian Tindakan Kelas (PTK) ini dirasa sangat cocok digunakan, karena penelitian ini difokuskan pada permasalahan pembelajaran yang timbul dalam kelas, guna untuk memperbaiki pembelajaran dan meningkatkan proses belajar mengajar yang lebih efektif. PTK dipilih karena mempunyai beberapa keistimewaan yaitu mudah dilakukan oleh guru, tidak mengganggu jam kerja guru, selain itu sambil mengajar bisa sekaligus melakukan penelitian serta tidak memerlukan perbandingan. Pada Penelitian Tindakan Kelas ini, secara garis besar terdapat 4 tahapan yang sudah lazim digunakan, yaitu tahap perencanaan, pelaksanaan, pengamatan dan refleksi. Maka dari itu sub bab ini menyajikan paparan data yang mendukung pelaksanaan penelitian tindakan kelas yang dilakukan oleh peneliti. Data hasil penelitian yang akan dipaparkan adalah hasil penelitian tentang peningkatan hasil belajar IImu Pengetahuan Alam materi siklus air menggunakan model Problem Based Learning dengan Media Diorama, dengan mengacu pada tujuan penelitian yaitu untuk peningkatan hasil belajar yang diperoleh peserta didik..

Berdasarkan hasil tes pra tindakan tergambar bahwa dari 27 peserta didik kelas V SD Negeri Kluwut 04 yang mengikuti tes, 23 peserta didik atau 88\% belum mencapai batas ketuntasan yaitu nilai 75 , sedangkan yang telah mencapai batas tuntas yaitu memperoleh nilai di atas 75 sebanyak 4 peserta didik atau hanya 12\%. Setelah mengamati secara proses pembelajaran Tematik kelas $\mathrm{V}$ pada tahap tes awal atau Pra Siklus, kemudian peneliti sebagai guru wali kelas merencanakan tindakan untuk tahap berikutnya yaitu tahap Siklus I untuk meningkatkan hasil belajar IPA peserta didik. Sebelum melaksanakan Siklus I ada beberapa hal yang perlu di identifikasi yaitu, pelaksanaan pembelajaran masih pada komunikasi satu arah, model pembelajaran yang digunakan belum mampu meningkatkan hasil belajar IPA materi siklus air, dan pembelajaran yang ada di kelas berkaitan dengan media pembelajaran belum efektif.

Observasi pada siklusl dilakukan oleh observer. Observer dalam penelitian ini adalah rekan sesama guru. Observer diminta untuk mengisi lembar observasi yang telah disiapkan (terlampir). Lembar observasi terdiri dari pengamatan terhadap guru dan peserta didik. Hasil observasi kinerja guru di siklus I memiliki skor 75 dengan presentase $62,5 \%$. Dengan skor tersebut membuat kinerja guru di siklus II berada pada kategori cukup. Sedangkan hasil penilaian observasi peserta didik pada siklus I memiliki nilai skor 69 dengan presentase 57,5\%. Skor tersebut membuat kondisi peserta didik di siklus I berada pada kategori cukup. Hasil tes akhir siklus I diperoleh nilai rata-rata peserta didik 77 . Dari hasil tes akhir siklus I tersebut, hasil belajar peserta didik sudah mengalami peningkatan bila di bandingkan dengan hasil tes akhir pra tindakan. 20 peserta didik telah memperoleh nilai diatas 75 , sudah memenuhi kriteria ketuntasan minimum. Persentase ketuntasan belajar pada siklus I adalah $74 \%$, yang berarti persentase ketuntasan belajar peserta didik belum memenuhi kriteria ketuntasan yang telah ditentukan, yaitu $85 \%$. Sehingga masih perlu diadakan siklus selanjutnya, yaitu siklus ke 2 . 
Setelah pelaksanaan pembelajaran siklus II, hasil observasi kinerja guru di siklus II memiliki skor 93 dengan presentase $77,5 \%$. Dengan skor tersebut membuat kinerja guru di siklus II berada pada kategori baik. Sedangkan hasil penilaian observasi peserta didik pada siklus II memiliki nilai skor 89 dengan presentase $74,2 \%$. Skor tersebut membuat kondisi peserta didik di siklus II berada pada kategori baik. Ketuntasan klasikal yang diperoleh peserta didik pada siklus II sebanyak (100\%) atau sebanyak 27 peserta didik yang telah tuntas dalam menjawab soal yang telah diberikan, sementara itu sebanyak $0 \%$ atau 0 peserta didik yang belum tuntas dalam menjawab soal yang diberikan. Ini membuktikan bahwa hasil belajar peserta didik pada mata pelajaran IPA materi siklus air sudah sangat baik dan ketuntasan hasil belajar peserta didiksecara klasikal telah tercapai. Oleh karena itu siklus selanjutnya tidak dilaksanakan lagi.

Peningkatan hasil belajar peserta didik dapat dilihat dari ketuntasan belajar dengan Kriteria Ketuntasan Minimal (KKM) yang ditetapkan adalah 75. Terbukti pada hasil tes awal, dari 27 peserta didik yang mengikuti tes, peserta didik yang tuntas belajar hanya 4 peserta didik dan 23 peserta didik tidak tuntas belajar. Dengan persentase ketuntasan belajar 12\%. Meningkat pada hasil tes siklus I ketuntasan mencapai $74 \%$ dan pda siklus ke II mencapai 100\%.

Tabel 1 Perbandingan Data Pratindakan, Siklus I dan Siklus II

\begin{tabular}{lc}
\hline \multicolumn{1}{c}{ Siklus } & Prosentase Ketuntasan \\
\hline Pratindakan & $12 \%$ \\
\hline Siklus I & $74 \%$ \\
\hline Siklus II & $100 \%$ \\
\hline
\end{tabular}

Berdasarkan tabel di atas dapat ditarik kesimpulan bahwa penerapan model pembelajaran Problem Base Learning dengan media Diorama dapat meningkatkan hasil belajar peserta didik sekaligus menunjukkan bahwa peserta didik merasa senang melaksanakan model pembelajaran Problem Base Learning dengan media Diorama. Model pembelajaran Problem Based Learning menunjukan peserta didik bisa lebih aktif dalam kegiatan pembelajaran. Hal tersebut sejalan dangan tujuan penulis yaitu untuk peningkatan hasil belajar IPA peserta didik.

\section{SIMPULAN}

Berdasarkan hasil penelitian tindakan kelas menerapkan model pembelajaran Problem Based Learning dengan media Diorama pada Kelas V Tema 8 Lingkungan Sahabat Kita untuk meningkatkan hasil belajar IPA dapat disimpulkan bahwa: Penerapan model Problem Based Learning dengan media Diorama dapat meningkatkan hasil belajar IPA materi Siklus Air peserta didik. Data peningkatan kemampuan tersebut diperoleh berdasarkan atas prosentase nilai hasil evaluasi. 27 peserta didik yang mengikuti tes, peserta didik yang tuntas belajar hanya 4 peserta didik dan 27 peserta didik tidak tuntas belajar dengan persentase ketuntasan belajar $12 \%$ dengan rata-rata nilai 55. Mengalami peningkatan pada hasil tes siklus I ketuntasan mencapai $74 \%$ dengan rata-rata nilai 77 dan pada siklus ke II mencapai $100 \%$ dengan rata-rata nilai 97. 
DAFTAR PUSTAKA

Depdiknas. (2003). Undang-undang Republik Indonesia Nomor 20 tahun 2003 tentang Sistem Pendidikan Nasional. Diakses dari https://pusdiklat.perpusnas.go.id (diunduh 1 Desember 2018).

Huda, M. (2017). Model-model Pengajaran dan Pembelajaran. Yogyakarta: Pustaka Pelajar.

Kunandar. (2012) . Langkah Mudah Penelitian Tindakan Kelas. Jakarta: Rajawali Pers. Muhsetyo, G. 2014. Pembelajaran Matematika SD, Jakarta: Universitas Terbuka.

Rivai, B \& Nana Sudjana. (2011). Media Pembelajaran. Bandung: Sinar Baru

Rusman. (2014). Model-Model Pembelajaran Mengembangkan Profesionalisme Guru. Jakarta: Rajawali Pers.

Rusmono. (2017). Strategi Pembelajaran dengan Problem Based Learning Itu Perlu Untuk Menciptakan Profesionalitas Guru Edisi Kedua. Bogor: Ghalia Indonesia.

Sa'ud, A. (2013). Instrumen perangkat pembelajaran. Bandung : Remaja Rosdakarya.

Susanto, A. (2013). Teori Belajar dan Pembelajaran di Sekolah Dasar. Jakarta: Kencana Prenadamedia Group.

Suyadi. (2010). Panduan Penelitian Tindakan Kelas. Yogyakarta: Diva Press.

Yusuf, Amin. (2014). Analisis Kebutuhan Pendidikan Masyarakat. Jurnal Penelitian Pendidikan. 31(2). 78. 